\title{
STUDI PENGEMBANGAN JARINGAN JALAN MENGGUNAKAN METODE AHP DAN GIS UNTUK KOTA TANJUNGBALAI
}

\section{Rozaqon Insani Lubis, Ahmad Perwira Mulia}

Universitas Sumatera Utara (USU) Indonesia

Email: rozaqoninsanilubi.1994@gmail.com, a.perwira.mulia@gmail.com

\begin{tabular}{|c|c|}
\hline INFO AR & ABSTRAK \\
\hline Diterima & \multirow{22}{*}{ 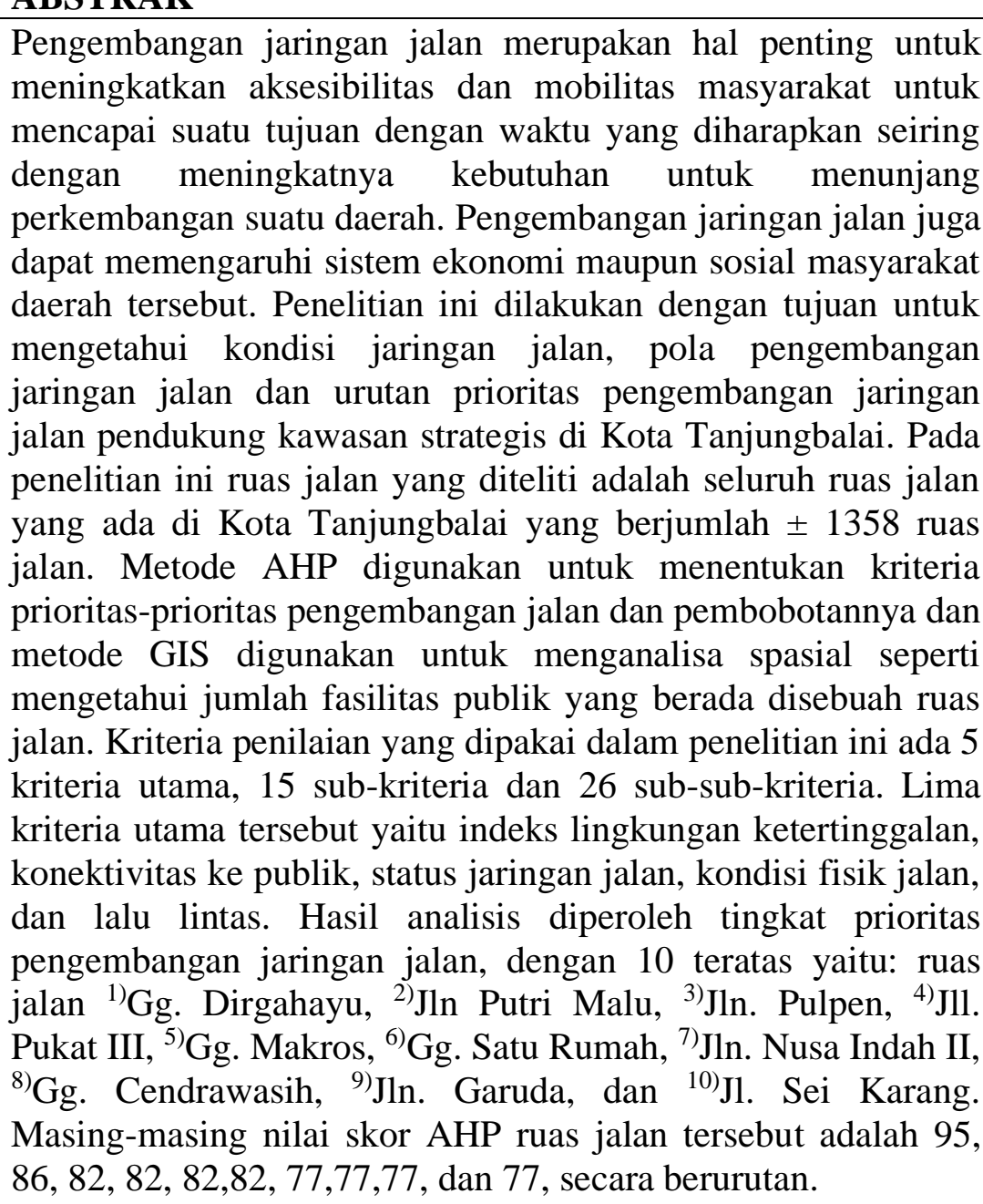 } \\
\hline 2 & \\
\hline Dile & \\
\hline 05 September 2021 & \\
\hline D & \\
\hline & \\
\hline Kata K & \\
\hline & \\
\hline keputusan & \\
\hline & \\
\hline & \\
\hline & \\
\hline & \\
\hline & \\
\hline & \\
\hline & \\
\hline & \\
\hline & \\
\hline & \\
\hline & \\
\hline & \\
\hline & \\
\hline
\end{tabular}

\section{ABSTRACT}

The development of road network is important thing to increase people's accessibility and mobility to reach their destination on time, along with the increase in needs for supporting a regional development. It can also influence people's socioeconomic system in that region. The objective of this research was to find out the condition of road network, the pattern of

$\begin{array}{lllll}\text { How to cite: } & \text { Lubis, R. I., \& Mulia, A. P. (2021) } & \text { Studi Pengembangan Jaringan Jalan Menggunakan Metode AHP } \\ & \text { dan GIS untuk Kota Tanjungbalai. } & \text { Jurnal Syntax Admiration } & \text { 2(9). } \\ & \text { https://doi.org/10.46799/jsa.v2i9.307 } & & \\ \text { E-ISSN: } & \text { 2722-5356 } & & & \\ \text { Published by: } & \text { Ridwan Institute }\end{array}$




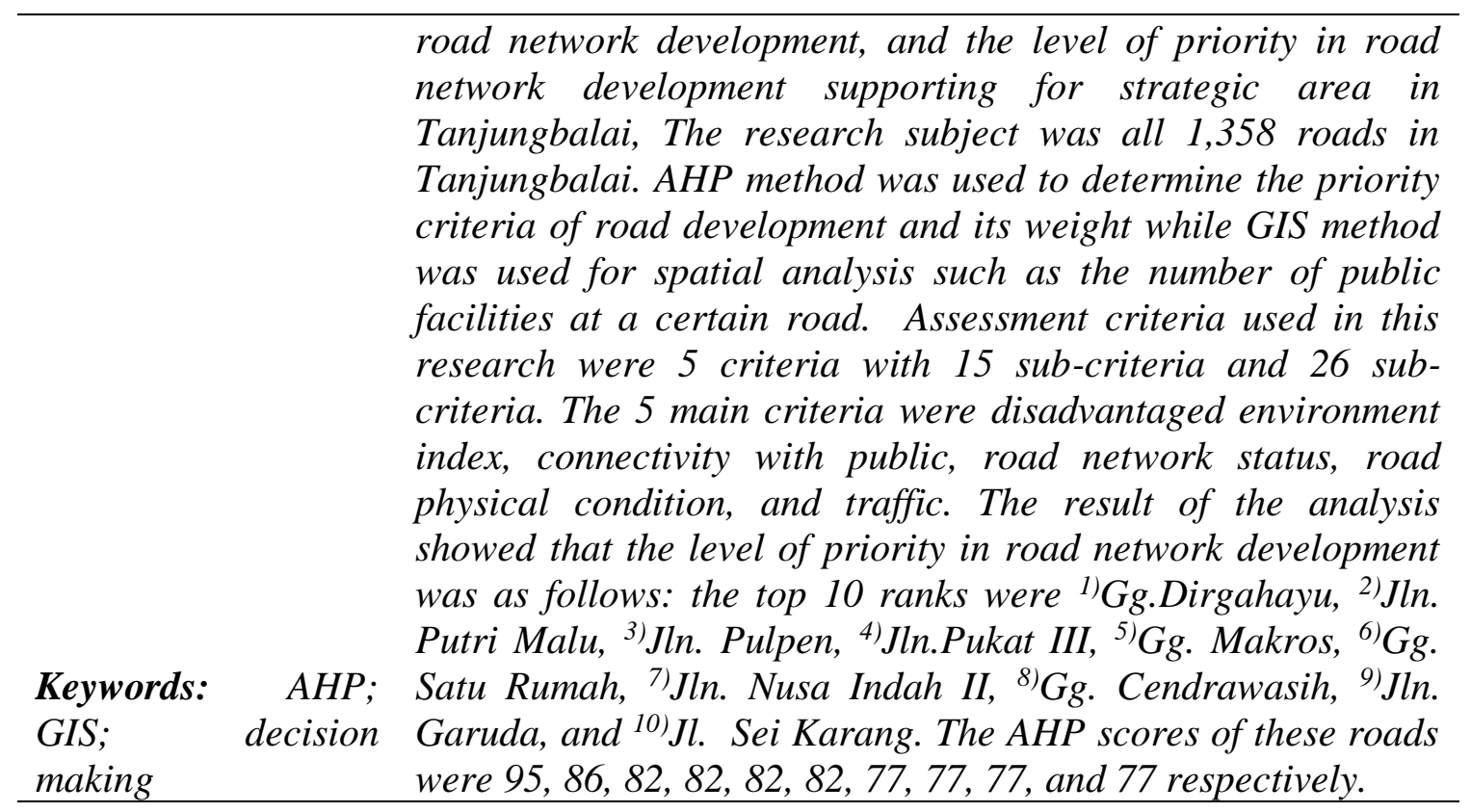

\section{Pendahuluan}

Sistem penataan kota biasanya terdapat hubungan antara tata guna lahan, demografi dan transportasi. Transportasi itu dapat dilihat sebagai fungsi dari beberapa sub sistem, seperti transportasi pribadi, transportasi publik dan transportasi barang (Örn, 2002).

Lalu lintas merupakan permasalahan yang dihadapi kota-kota besar di Indonesia, yang berawal dari penurunan kinerja jalan hingga pada akhirnya menimbulkan kemacetan lalu lintas. Beberapa faktor yang menyebabkan permasalahan tersebut antara lain urbanisasi, pertumbuhan penduduk yang pesat, pertumbuhan ekonomi dan pertumbuhan lalu lintas yang tinggi (Rahim \& Sutomo, 2001) dalam (Siregar, 2008). Menurut Indonesia Highway Capacity Manual/IHCM Part-II Road, tingkat kelancaran dan keselamatan lalu lintas dipengaruhi oleh berapa faktor yaitu: (1) kondisi kegiatan penduduk dan pola penggunaan lahan sekitar ruas jalan, (2) kondisi persimpangan sepanjang jalan, (3) kondisi trase jalan, (4) kondisi volume lalu lintas, dan (5) kondisi kecepatan kenderaan (Hotrin, 2011).

Peningkatan fasilitas prasarana di perkotaan dapat dilakukan dari beberapa sisi, salah satunya dengan pengembangan jaringan jalan. Pengembangan jaringan jalan di perkotaan sangat diperlukan untuk meningkatkan taraf hidup dan mempermudah kelangsungan hidup masyarakat di daerah tersebut. Seiring dengan pertumbuhan penduduk yang semakin meningkat, pembangunan prasarana jaringan dibutuhkan untuk menunjang pertumbuhan-pertumbuhan ekonomi terutama pada kawasan strategis yang sangat memengaruhi pergerakan masyarakat.

Sistem jaringan transportasi dicerminkan dalam bentuk ruas dan simpul, yang semuanya dihubungkan ke pusat zona. Hambatan pada setiap ruas jalan dinyatakan dengan jarak, waktu tempuh, atau biaya gabungan. Nilai tersebut kemudian dijumlahkan 
untuk mendapatkan total hambatan untuk setiap zona asal dan tujuan. Semua ini dapat dinyatakan dalam bentuk matriks (Tamin, 2000).

Analytical Hierarchy Process Method (AHP) merupakan metode dalam mengambil sebuah keputusan, yang dilakukan secara rasional dengan melakukan penyeleksian yang terbaik dari beberapa alternatif yang dievaluasi dengan multi kriteria. Para pengambil keputusan mengabaikan perbedaan yang kecil dalam proses ini dan selanjutnya mengembangkan seluruh prioritas dari beberapa alternatif. Dalam metode AHP, hirarki disusun dari atas ke bawah yang berawal dari tujuan, kriteria dan akhirnya pemilihan alternatif keputusan (Saaty, 1993).

Menurut (Dalal et al., 2010), dalam penelitiannya yang berjudul Prioritization of Rural Roads: AHP in Group Decision memilih kriteria indeks keketertinggalanan, konektivitas ke pelayanan, konektivitas ke jaringan jalan, kepadatan penduduk, kondisi jaringan jalan, volume lalu lintas dalam penelitiannya pada ruas jalan di kota India. Sedangkan (Afriansyah et al., 2012) melakukan penelitian penentuan prioritas pengembangan jaringan jalan pendukung kawasan strategis di pulau Sumbawa (Nusa Tenggara Barat) menggunakan kriteria Lalu lintas, tata ruang, ekonomi, lingkungan, pariwisata, finansial.

Menurut (Hotrin, 2011) dalam tulisannya yang berjudul Analisis Prioritas Penanganan Jaringan Jalan Strategis Terhadap Pengembangan Wilayah Di Kabupaten Humbang Hasundutan memilih aksesibilitas, peningkatan hubungan antar daerah, kemudahan transportasi, penghematan waktu tempuh sebagai kriteria dalam penelitian ruas jalan yang dilakukan. Sedangkan (Abdurrahman et al., 2015) menggunakan kriteria karakteristik lalu lintas, tata guna lahan, kondisi perkerasan, preferensi dalam memodelkan dan menentukan peringkat prioritas jalan perkotaan untuk program pemeliharaan berdasarkan pengambilan keputusan multi kriteria di Makassar (Munthe et al., 2015). Menyimpulkan bahwa kriteria yang paling dominan dalam penanganan ruas jalan nasional di pulau Bangka adalah aksesibilitas diikuti dengan mobilitas, kondisi ruas jalan, arus lalu lintas, pengembangan wilayah dan ekonomi.

Menurut Simatupang di dalam (Akbar, 2018) aksesibilitas adalah sebuah konsep yang digunakan di sejumlah bidang ilmiah seperti perencanaan transportasi, perencanaan kota dan geografi, memainkan peran penting dalam pembuatan Perspektif mobilitas Indikator kinerja.

QGIS (Quantum GIS) adalah aplikasi sistem informasi geografis berbasis terbuka dan bebas lintas platform yang menyediakan tampilan, penyuntingan, dan analisis data. QGIS mempunya fungsi yang hampir sama dengan software GIS lainnya, yang memungkinkan pengguna untuk membuat peta dengan banyak lapisan menggunakan proyeksi peta. Peta dapat digunakan dalam format yang berbeda berdasarkan keperluannya masing-masing.

Pengolahan masalah tingkat prioritas juga dapat menggunakan QGIS. Tingkat prioritas tersebut dapat diinput kedalam atribut layer yang digunakan, sehingga pada peta yang ada dapat dilihat tingkat pengelompokan prioritas dari tingkat yang paling tinggi ke tingkat yang paling rendah. 
Penelitian ini bertujuan untuk menentukan tingkat prioritas pengembangan jaringan jalan di Kota Tanjungbalai dengan menggunakan metode AHP dan GIS. Kriteria yang digunakan dalam metode $A H P$ ada 5 kriteria utama, 15 sub-kriteria dan 26 sub-sub-kriteria. Kriteria tersebut yaitu Indeks Lingkungan Ketertinggalan, Konektivitas ke Publik, Status Jaringan Jalan, Kondisi Fisik Jalan, dan Lalu Lintas. Untuk mempermudah melihat urutan prioritas penanganan berdasarkan informasi spasialnya, digunakan software QGIS. Dengan bantuan software ini, urutan prioritas berdasarkan masing-masing kriteria yang ada dapat dianalisis dan ditampilkan secara zonasi di monitor. Ruas jalan yang diteliti akan langsung digambarkan pada peta lokasi penelitian.

Menurut RTRW Kota Tanjungbalai tahun 2013-2033, ruang lingkup wilayah perencanaan RTRW adalah sebagai berikut:

1. Batas wilayah perencanaan RTRW meliputi :

a. Sebelah Utara berbatasan dengan Desa Pematang Sei Baru Kecamatan Tanjungbalai, Kabupaten Asahan.

b. Sebelah Selatan berbatasan dengan Desa Sei Dua Hulu Kecamatan Simpang Empat, Kabupaten Asahan.

c. Sebelah Barat berbatasan dengan Kecamatan Air Joman dan Kecamatan Simpang Empat, Kabupaten Asahan.

d. Sebelah Timur berbatasan dengan Sungai Asahan/Kecamatan Sungai Kepayang, Kabupaten Asahan.

2. Cakupan wilayah perencanaan RTRW meliputi seluruh wilayah administrasi Kota Tanjungbalai dengan luas 6.052 hektar yang mencakup enam kecamatan, meliputi:

a. Kecamatan Datuk Bandar dengan luas 2.249 ha

b. Kecamatan Datuk Bandar Timur dengan luas 1.457 ha

c. Kecamatan Datuk Bandar Selatan dengan luas 198 ha

d. Kecamatan Tanjungbalai Utara dengan luas 84 ha

e. Kecamatan Sei Tualang Raso dengan luas 809 ha

f. Kecamatan Teluk Nibung.1.255 ha

Penelitian dilakukan terhadap seluruh ruang lingkup wilayah yang terdapat di Kota Tanjungbalai tersebut. Hasil dari penelitian ini diharapkan dapat menjadi masukan kepada instansi terkait dalam pemilihan kegiatan penegembangan jalan di kota Tanjung Balai.

Penelitian terdahulu juga telah dilakukan dengan metode yang relevan dengan penelitian ini, seperti yang dilakukan oleh (Serena, 2014) yang melakukan studi kelayakan pengembangan jaringan jalan untuk mendukung industry pertanian di kabupaten Sunbawa Barat. Hasil analisis menunjukkan bahwa jalan lintas timur dan jalan lintas selatan yang mendukung sektor pertanian di Kabupaten Sumbawa Barat mempunyai nilai NPV (Net Present Value) positif dan BCR (Benefit Cost Ratio) lebih besar dari 1sehingga jalan tersebut layak untuk dilaksanakan. Selain itu, (Ali et al., 2012) juga telah melakukan studi pengembangan jaringan jalan kabupaten di kabupaten Pinrang-Sulawesi Selatan berbasis metode analisis multi kriteria dengan mengunakan 
pendekatan $A H P$ sehingga diperoleh alternatif pembuatan jalan baru lebih diprioritaskan daripada perbaikan jalan dalam pengembangan jaringan transportasi kabupaten Pinrang. Tidak hanya itu, (Saputra et al., 2020) juga menggunakan metode AHP dan GIS untuk zonasi daerah rawan banjir rob di wilayah Medan Utara. (Yudi, 2015) dalam jurnalnya mengemukakan sistem pendukung keputusan pemilihan perumahan metode $A H P$ dan GIS statis kota Medan sebagai salah satu kriteria pemilihan. Sistem pendukung keputusan ini membantu melakukan penilaian setiap perumahan, melakukan perubahan kriteria, dan perubahan nilai skor. Hal ini berguna untuk memudahkan pengambilan keputusan yang terkait dengan masalah pemilihan perumahan yang baik, sehingga akan di dapatkan perumahan yang paling sesuai dengan keinginan calon pembeli perumahan. (Syafaruddin et al., 2021) juga melakukan analisis prioritas pengolahan DAS Deli menggunakan metode AHP-SYI dan Fuzzy AHP-SYI dalam format GIS untuk mendapatkan keputusan apakah diperlukan atau tidak pengolaan DAS tersebut.

\section{Metode Penelitian}

Penelitian ini dilakukan secara eksploratif, lapangan, kuantitatif dan kualitatif. Artinya data-data yang diperoleh dari lapangan. Data yang diperoleh akan dilakukan analisa pengambilan keputusan sehingga didapatkan keputusan yang mutlak. Selanjutnya dilakukan analisis menggunakan perangkat lunak AHP dan $Q G I S$.

Data yang digunakan dalam penelitian ini adalaha data primer dan data sekunder. Data primer berupa data konektivitas ke publik diperoleh dari google earth, data volume kendaraan, dan peta lokasi penelitian diperoleh dari website BAPPEDA kota Tanjung Balai. Data sekunder yang digunakan dalam penelitian ini adalah data yang diperoleh dari Dinas Bina Marga dan Dinas BAPPEDA Tanjungbalai meliputi data karakteristik jalan yakni nama jaringan jalan, kondisi jaringan jalan, status jaringan jalan dan LHR kenderaan.

Data yang diperoleh, dikumpulkan dan diolah berdasarkan masing-masing ruas jalan yang diteliti. Kemudian dilakukan pembuatan hirarki keputusan dalam menentukan setiap kriteria terhadap jaringan jalan yang akan digunakan dalam analisis AHP. Penentuan kriteria dilakukan berdasarkan studi terdahulu yang telah dilakukan sebelumnya melalui jurnal-jurnal.

Langkah selanjutnya adalah mendapatkan kriteria yang akan digunakan, dilanjutkan dengan tahapan perhitungan bobot setiap kriteria. Bobot yang diberikan berdasarkan tingkat pengelompokan masing-masing kriteria. Pemberian pembobotan setiap keriteria dihitung berdasarkan tingkat prioritas kepentingan dari masing-masing keriteria. Setelah itu dilakukan analisis menggunakan AHP dan QGIS untuk kemudian dibahas dan disimpulkan. 
Berikut tahapan pelaksanaan penelitian ini disajikan pada skema pada Gambar 1.

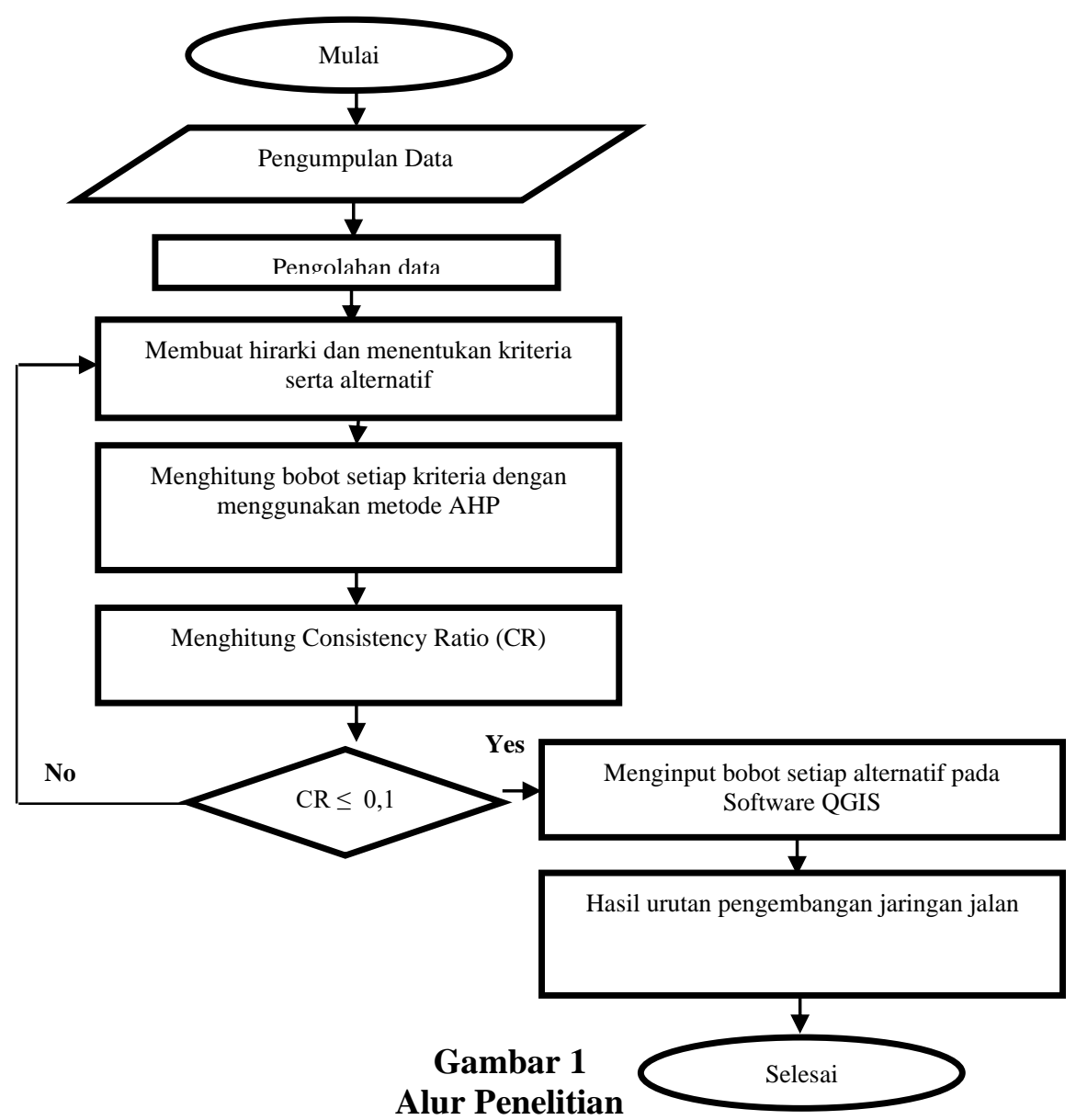

\section{Hasil dan Pembahasan}

\section{Analisa Menggunakan Metode $A H P$}

Motivasi utama penggunaan $A H P$ adalah untuk menghitung bobot setiap kriteria, sub-kriteria serta sub-sub-kriteria yang ada, dengan cara melakukan perhitungan matriks perbandingan berpasangan. Selanjutnya, nilai sintesis matriks dapat diproses untuk kemudian menghitung nilai $\mathrm{CR}<0,1$ dalam rangka mengecek konsistesinya.

Kriteria AHP dilakukan dengan metode expert judgement atau dengan metode yang disepakati oleh para ahli (stakeholders) serta berdasarkan jurnal-jurnal ilmiah yang terkait dengan penelitian ini. Kriteria penilaian yang telah dijelaskan, yaitu:

- Indeks lingkungan ketertinggalan (ILK)

- Konektivitas ke publik (KP)

- Status jaringan jalan (SJ)

- Kondisi fisik jalan (KFJ)

- Lalulintas (LL) 
Penilaian bobot antar kriteria tersebut dilakukan dengan Focus Group Discussion yang melibatkan para ahli dari Universitas Sumatera Utara. Hasil dari diskusi tersebut dapat dilihat pada skema skala perbandingan antara dua kriteria pada Gambar 2: Skala Perbandingan.

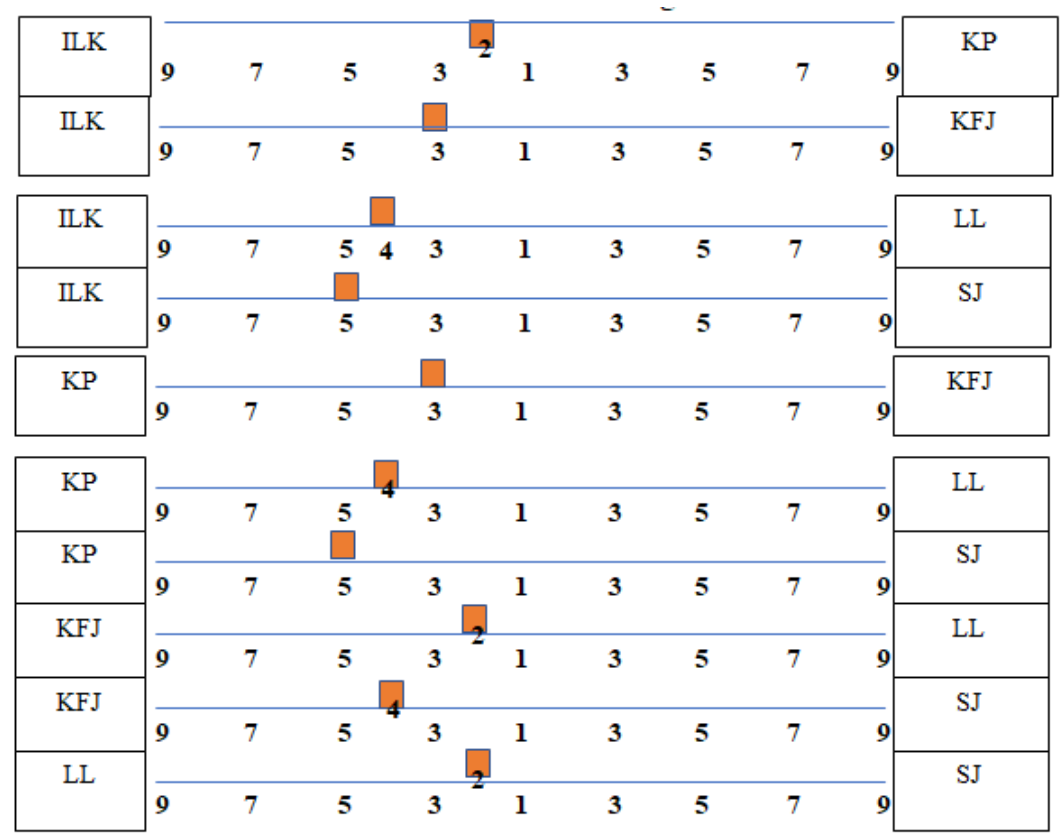

Gambar 2

Skema Skala Perbandingan Dua Alternatif

Proses perhitungan matriks perbandingan berpasangan $A H P$ dapat dipecah dalam 2 tahapan, yaitu:

1. Tahapan Penyusunan Matriks Dan Perhitungan Bobot

Tahapan ini meliputi penyusunan matriks dari seluruh kriteria yang ada dan disusun pada Tabel 1, kemudian nilai matriks tersebut dirubah menjadi desimal seperti terlihat pada Tabel 2.

Tabel 1

Matriks Perbandingan Kriteria

\begin{tabular}{cccccc}
\hline \multicolumn{7}{c}{ Matriks Perbandingan } \\
\hline Kriteria & ILK & KP & SJ & KFJ & LL \\
\hline ILK & 1 & 2 & 5 & 3 & 4 \\
\hline KP & $1 / 2$ & 1 & 5 & 3 & 4 \\
\hline SJ & $1 / 5$ & $1 / 5$ & 1 & $1 / 4$ & $1 / 2$ \\
\hline KFJ & $1 / 3$ & $1 / 3$ & 4 & 1 & 2 \\
\hline LL & $1 / 4$ & $1 / 4$ & 2 & $1 / 2$ & 1 \\
\hline
\end{tabular}

Sumber: Hasil Analisa 
Tabel 2

Matriks Perbandingan Kriteria

\begin{tabular}{cccccc}
\hline \multicolumn{7}{c}{ Matriks Perbandingan } \\
\hline Kriteria & ILK & KP & SJ & KFJ & LL \\
\hline ILK & 1 & 2 & 5,0 & 3,0 & 4,0 \\
\hline KP & 0,500 & 1 & 5 & 3 & 4 \\
\hline SJ & 0,200 & 0,200 & 1 & 0,250 & 0,500 \\
\hline KFJ & 0,333 & 0,3 & 4 & 1 & 2 \\
\hline LL & 0,250 & 0,250 & 2 & 0,50 & 1 \\
\hline Total & 2,28 & 3,78 & 17,00 & 7,75 & 11,50 \\
\hline
\end{tabular}

\section{Sumber: Hasil Analisa}

Langkah selanjutnya adalah menyusun matriks perbandingan dalam sebuah tabel, maka dilakukan perhitungan sintesis matriks menggunakan nilai kriteria yang ada Tabel 3.

Tabel 3

Sintesis Matriks Kriteria

\begin{tabular}{ccccccc}
\hline \multicolumn{7}{c}{ Sintesis Matriks } \\
\hline Kriteria & ILK & KP & SJ & KFJ & LL & $\begin{array}{c}\text { Vector } \\
\text { Prioritas }\end{array}$ \\
\hline ILK & 0,438 & 0,529 & 0,294 & 0,387 & 0,348 & 0,399 \\
\hline KP & 0,219 & 0,264 & 0,294 & 0,387 & 0,348 & 0,302 \\
\hline SJ & 0,088 & 0,053 & 0,059 & 0,032 & 0,043 & 0,055 \\
\hline KFJ & 0,146 & 0,088 & 0,235 & 0,129 & 0,174 & 0,154 \\
\hline LL & 0,109 & 0,066 & 0,118 & 0,065 & 0,087 & 0,089 \\
\hline & 1,00 & 1,00 & 1,00 & 1,00 & 1,00 & 1,00 \\
\hline
\end{tabular}

Sumber: Hasil Analisa

2. Tahapan Perhitungan Konsistensi

Tahapan ini dilakukan perhitungan konsistensi untuk melihat nilai hasil $A H P$ memenuhi persyaratan $\mathrm{CR}<0,1$ atau tidak. Apabila nilai konsistensi tidak terpenuhi, maka dilakukan kembali perhitungan $A H P$ dengan cara tahap 1 yang sebelumnya. Untuk mendapatkan nilai rasio, maka dilakukan perhitungan $\lambda \max$ terlebih dahulu dengan cara sebagai berikut:

$$
\begin{array}{r}
0,399\left\{\begin{array}{c}
1 \\
1 / 2 \\
1 / 5 \\
1 / 3 \\
1 / 4
\end{array}\right\}+0.302\left\{\begin{array}{c}
2 \\
1 \\
1 / 5 \\
1 / 3 \\
1 / 4
\end{array}\right\}+0,154\left\{\begin{array}{l}
5 \\
5 \\
1 \\
4 \\
2
\end{array}\right\} \\
+0,089\left\{\begin{array}{c}
3 \\
3 \\
1 / 4 \\
1 \\
1 / 2
\end{array}\right\}+0,055\left\{\begin{array}{l}
4 \\
4 \\
1 / 2 \\
2 \\
1
\end{array}\right\}=\left\{\begin{array}{l}
2,098 \\
1,596 \\
0,278 \\
0,786 \\
0,452
\end{array}\right\}
\end{array}
$$


Hasil perkalian matriks di atas dibagi lagi dengan bobot dari setiap kriteria tersebut:

$$
\begin{array}{lll}
\frac{2,098}{0,399}=5,258 & \frac{0,278}{0,055}=5,055 & \frac{0,452}{0,089}=5,079 \\
\frac{1,596}{0,302}=5,285 & \frac{0,786}{0,154}=5,104
\end{array}
$$

Kemudian dari hasil pembagian di atas, dihitung nilai $\lambda$ max, sebagai berikut:

$$
\begin{aligned}
\lambda \max & =\frac{5,258+5,258+5,055+5,104+5079}{5} \\
\lambda \max & =5,153
\end{aligned}
$$

Tahapan selanjutnya adalah menghitung nilai concistency ratio index (CI) dan menghitung nilai concistency ratio (CR) dengan menggunakan nilai random consistency (RI) dengan nilai $\mathrm{RI}=1,21$ untuk $\mathrm{n}=5$. Perhitungan $\mathrm{CI}$ dan $\mathrm{CR}$ adalah sebagai berikut:

$$
\begin{aligned}
\mathrm{CI} & =\frac{\lambda \max -\mathrm{n}}{\mathrm{n}-1}=\frac{5,153-5}{5-1}=0,038 \\
\mathrm{CR} & =\frac{\mathrm{CI}}{\mathrm{RI}}=\frac{0,038}{1,21}=0,034<0,1
\end{aligned}
$$

Hasil dari seluruh perhitungan nilai $A H P$ diatas, ditabulasikan kedalam Tabel

3. Perhitungan Perioritas Pengembangan Jaringan Jalan Menggunakan Software Qgis

Perhitungan prioritas pemengembangan jalan menggunakan Software Qgis dilakukan setelah diperoleh bobot dari setiap kriteria penilaian. Penentuan prioritas dilakukan dengan cara memberi skor terlebih dahulu terhadap masingmasing kriteria penilaian tersebut berdasarkan jumlah yang ada pada setiap jaringan jalan. Setelah menetukan skor dari masing-masing kriteria, selanjutnya dilakukan analisa Qgis. Hasil dari setiap kriteria akan dijelaskan dalam bentuk peta. 


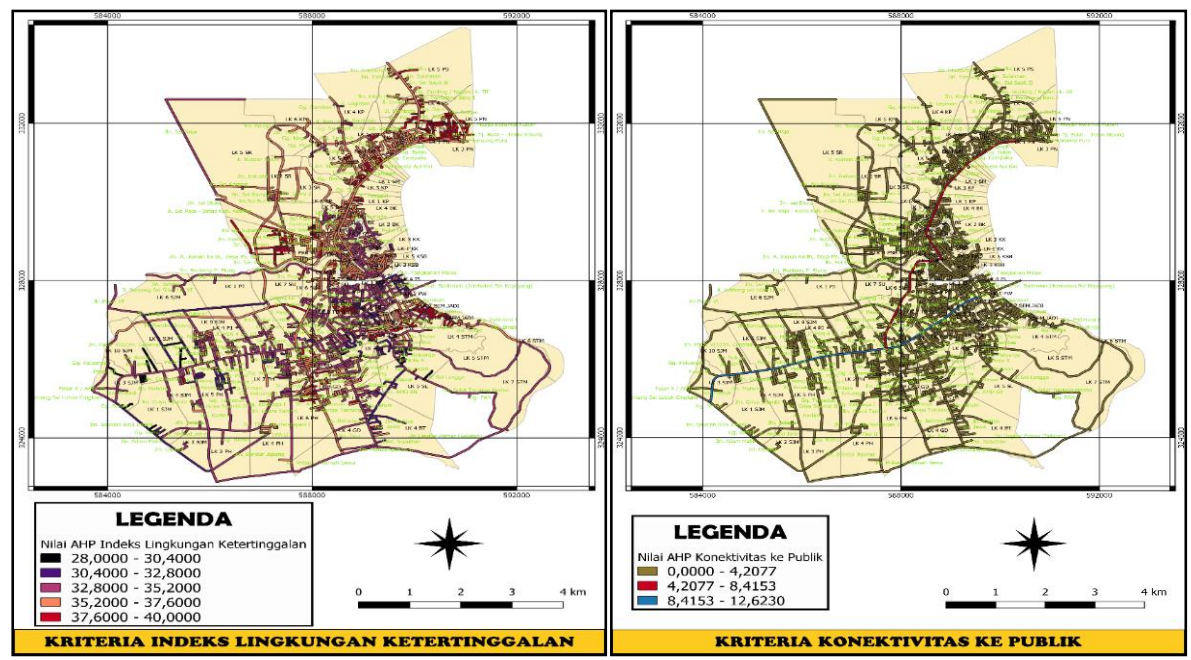

Gambar 3

Hasil analisa kriteria indeks lingkungan kumuh dan konektivitas ke public

4. Hasil Perhitungan Nilai $A H P$ Kriteria Utama

Tabel 4

Hasil Perhitungan Nilai $A H P$ Kriteria Utama

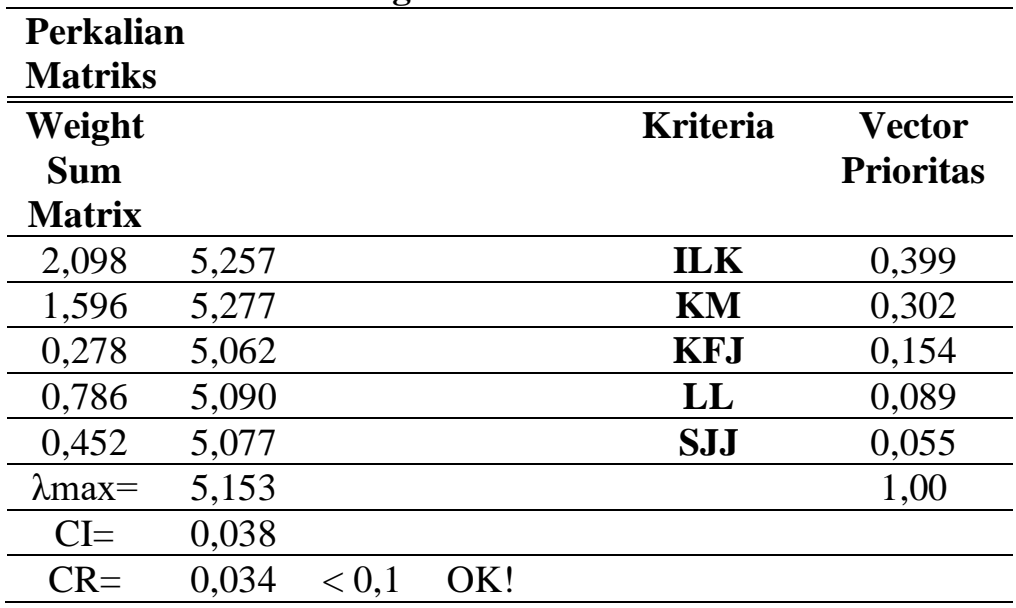

Langkah-langkah perhitungan di atas diulang kembali terhadap setiap kriteria penilaian sehingga diperoleh nilai bobot harus sesuai dengan persyaratan $\mathrm{CR}<0,1$. Dengan menggunakan cara yang sama seperti yang sebelumnya, dilakukan juga perhitungan nilai $A H P$ terhadap sub-kriteria dari masing-masing kriteria. 

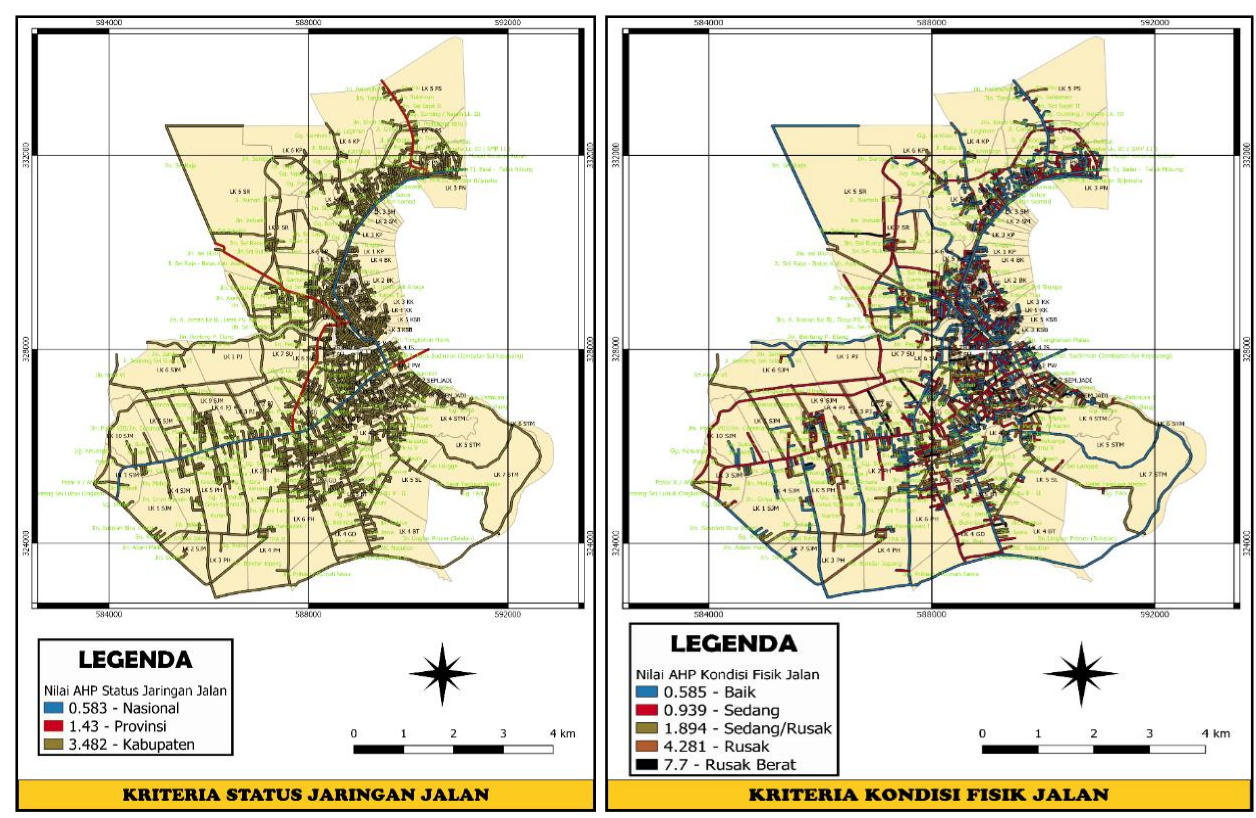

Gambar 4

Hasil Analisa Kriteria Status Jaringan

Jalan Dan Kriteria Kondisi Fisik Jalan

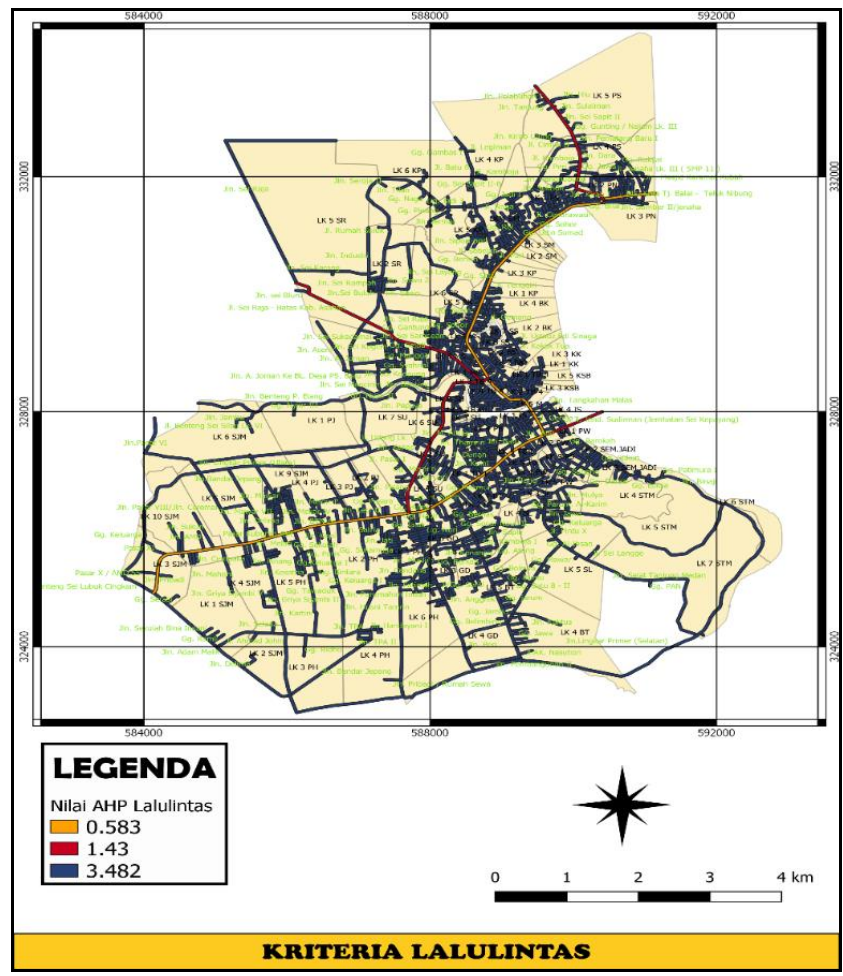

Gambar 5

Hasil Analisa Kriteria Lalulintas

Berdasarkan 5 kriteria penilaian dan terdiri dari 10 sub-kriteria penilaian, maka diperoleh hasil akhir dari analisa menggunakan Qgis. Hasil akhir ini dapat dilihat pada Gambar 6. 


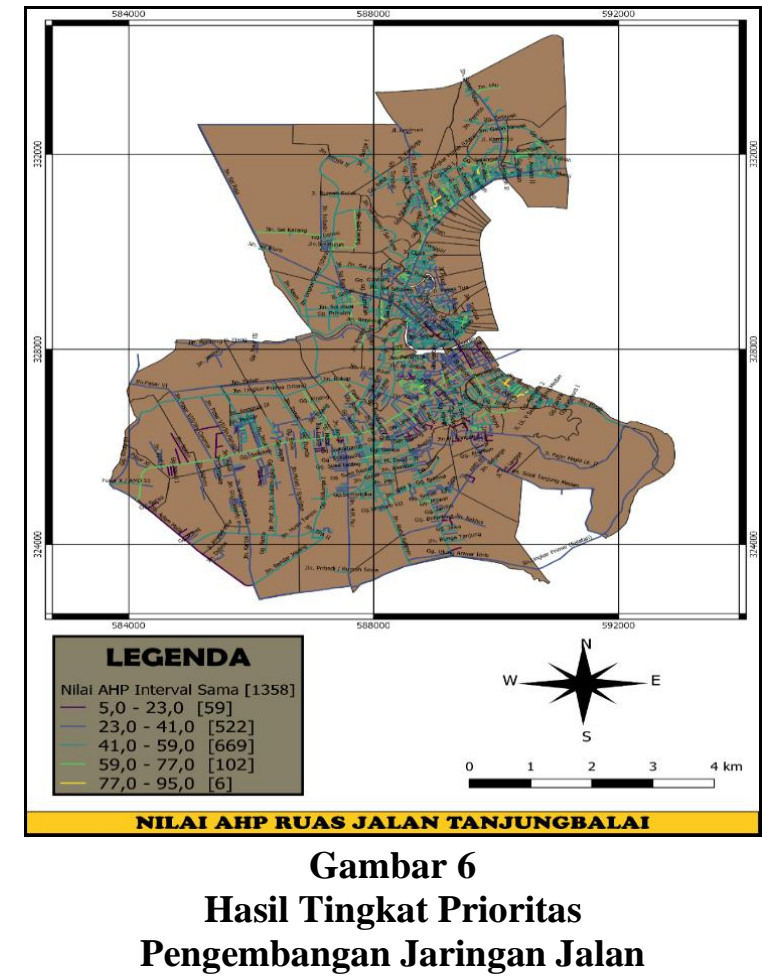

\section{Kesimpulan}

Berdasarkan hasil analisa dan pembahasan yang telah dilakukan, maka dapat disimpulkan bahwa tercatat 1358 ruas jalan di Kota Tanjungbalai yang memiliki panjang jalan terpendek $0,2 \mathrm{~km}$ dan panjang jalan terpanjang $6,5 \mathrm{~km}$ dengan kondisi fisik jalan yang terbagi atas kondisi baik (37\%), kondisi sedang/rusak (19\%), kondisi sedang (26\%), kondisi rusak (15\%), dan kondisi rusak berat $(2 \%)$.

Kriteria utama fisik dan non fisik yang mempengaruhi tingkat prioritas pengembangan jalan ditetapkan berdasarkan konsensus expert judgement dengan metode $A H \mathrm{P}$, sebagai berikut: kriteria indeks lingkungan ketertinggalan memiliki bobot 0,399 , kriteria konektivitas ke publik memiliki bobot 0,302 , kriteria kondisi fisik jalan memiliki kriteria 0,154, kriteria lalu lintas memiliki bobot 0,089, dan kriteria status jaringan jalan memiliki kriteria 0,055 .

Hasil prioritas jalan untuk sepuluh ruas jalan teratas berdasakan hasil analisa adalah jalan Gg. Dirgahayu dengan skor 95, jalan Putri Malu dengan skor 86, jalan Pulpen dengan skor 82, jalan Pukat III dengan skor 82, jalan Makros dengan skor 82, jalan Gg. Satu Rumah dengan skor 82, jalan nusa Indah II dengan skor 77, jalan Gg. Cendrawasih dengan skor 77, jalan Garuda dengan skor 77 dan jalan Sei Karang dengan skor 77 .

Hasil pengelompokan prioritas dapat dibagi menjadi 5 kelompok yaitu sangat rendah, rendah, sedang, tinggi dan sangat tinggi. Metode yang lebih proposional dari setiap kelompoknya adalah natural breaks. Metode pengelompokannya adalah seperti uyang diberikan pada Tabel 5. 


\section{BIBLIOGRAFI}

Abdurrahman, M. A., Samang, L., Adisasmita, S. A., \& Ramli, M. I. (2015). Modeling and Determining Urban Road Priority Rank for Maintenance Program Based on Multi-Criteria Decision Making in Makassar City, Indonesia. Traffic, 1, B3. Google Scholar

Afriansyah, R., Wicaksono, A., \& Djakfar, L. (2012). Penentuan prioritas pengembangan jaringan jalan pendukung kawasan strategis di pulau sumbawa. Rekayasa Sipil, 6 (3), 214-225. Google Scholar

Akbar, M. (2018). Analisis Prioritas Pengembangan Jaringan Jalan Untuk Mendukung Lumbung Pangan Nasional di Kabupaten Marauke. Tesis Teknik Perencanaan Transportasi. Google Scholar

Ali, N., Ramli, M. I., \& Hustim, M. (2012). Studi Pengembangan Jaringan Jalan Kabupaten di Kabupaten Pinrang Sulawesi Selatan Berbasis Metode Analisis Multi Kriteria. Jakarta, KoNTekS, 6, T41-T50. Google Scholar

Dalal, J., Mohapatra, P. K. J., \& Mitra, G. C. (2010). Prioritization of rural roads: AHP in group decision. Engineering, Construction and Architectural Management. Google Scholar

Hotrin, R. (2011). Analisis Prioritas Penanganan Jaringan Jalan Strategis Terhadap Pengembangan Wilayah di Kabupaten Humbang Hasundutan. Google Scholar

Munthe, R. B., Setiadji, B. H., \& Darsono, S. (2015). Menentukan Prioritas Penanganan Ruas Jalan Nasional di Pulau Bangka. Media Komunikasi Teknik Sipil, 21 (1), 5767. Google Scholar

Örn, H. (2002). Urban Traffic and Transport. Lund University, Housing Development and Management. Google Scholar

Rahim, R., \& Sutomo, H. (2001). Optimalisasi Beban As Truk dan Perhitungan Pajak Jalan Dalam Rangka Meminimalkan Biaya Transport (Studi Kasus: Jalan Lintas Timur Sumatera di Propinsi Riau). Media Teknik, 23 (2001). Google Scholar

Saaty, T. L. (1993). Pengambilan keputusan bagi para pemimpin, proses hirarki analitik untuk pengambilan keputusan dalam situasi yang kompleks. Pustaka Binama Pressindo, 100. Google Scholar

Saputra, N. A., Tarigan, A. P. M., \& Nusa, A. B. (2020). Penggunaan Metode AHP dan GIS Untuk Zonasi Daerah Rawan Banjir Rob di Wilayah Medan Utara. Media Komunikasi Teknik Sipil, 26 (1), 73-82. Google Scholar

Serena, A. R. (2014). Kelayakan Pengembangan Jaringan Jalan untuk Mendukung Industri Pertanian di Kabupaten Sumbawa Barat. Jurnal Transportasi, 14 (3). Google Scholar 
Rozaqon Insani Lubis, Ahmad Perwira Mulia

Siregar, H. (2008). Analisis Kinerja Jalan Akibat Peningkatan Intensitas Bangunan Perumahan Pada Kawasan Permukiman. Medan. Google Scholar

Syafaruddin, S., Mulia, A. P., \& Nasution, Z. P. (2021). Prioritisasi Pengelolaan DAS Deli Menggunakan Metode AHP-SYI dan Fuzzy AHP-SYI dalam Format GIS. Syntax Literate; Jurnal Ilmiah Indonesia, 6 (8), 4107-4126. Google Scholar

Tamin, O. Z. (2000). Perencanaan dan pemodelan transportasi. Penerbit ITB. Google Scholar

Yudi, Y. (2015). Sistem Pendukung Keputusan Pemilihan Perumahan Methode AHP Dan GIS Statis Kota Medan Sebagai Salah Satu Kriteria Pemilihan. Eksplora Informatika, 5 (1). Google Scholar

Copyright holder:

Rozaqon Insani Lubis, Ahmad Perwira Mulia (2021)

First publication right:

Jurnal Syntax Admiration

This article is licensed under:

(c) (7) (?) 